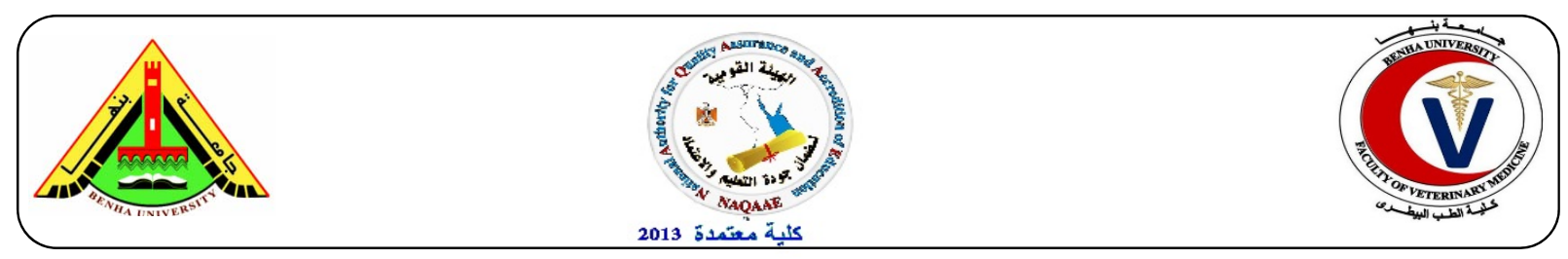

\title{
Molecular assay using PCR based technology to identify fraud and adulteration of some meat products
}

\author{
Eman El-Shazly ${ }^{1}$, Noha, M. El-Shinawy ${ }^{2}$, Khaled Shawky Tolba ${ }^{2}$ \\ ${ }^{1}$ Animal Health Research Institute, Food Hygiene Department, Tanta lab \\ ${ }^{2}$ Animal Health Research Institute, Food Hygiene Department, Dokki
}

\section{A B S T R A C T}

Meat species specification is a vital field to ensure the food safety to the consumers which corresponds to the laws related to meat and meat products. The adulteration of inferior quality meat into superior quality one is a common practice all over the world. In this study, 30 beef product samples including minced beef, luncheon and sausage (10 samples each) were collected from different markets in Cairo and Giza Governorate, transferred to the laboratory for detection of adulteration of beef with pig, equine and dog meat using Simple and reliable multiplex-polymerase chain reaction (multiplex-PCR) for the partial-length of cytochrome b (cyt b) gene of mitochondrial DNA (mtDNA) which indicated the successful detection of little as $0.05 \mathrm{ng} \%$ adulteration of meat products. Multiplex PCR can also be applied to detect authentication with equal efficiency to fresh, cooked or putrefied mixed meat samples. The obtained results revealed that one examined sample (10\%) of minced beef was intermixed with equine meat only, while two samples $(20 \%)$ of beef sausage were adulterated with addition of equine meat only. Moreover, the examined luncheon samples were free from adulteration with either pork or equine meat. All examined samples were found to be free from adulteration with dog meat. The bad effects of fraud and adulteration of meat products was discussed.

Keywords: Multiplex PCR, Authenticity, adulteration, beef, equine, pork and dog meat, mitochondrial DNA (mtDNA).

(http://www.bvmj.bu.edu.eg)

(BVMJ-31(2): 33-39, 2016)

\section{INTRODUCTION}

Identification of meat of different animal species is relevant to consumers for the possible economic losses from fraudulent adulterations, medical requirements of individuals that might have specific allergies. The main objective of identification of meat adulteration represented as religious reasons (Asensio et al., 2008a) for preparation of Halal food for the Muslim consumers, who are prohibited from consuming pork (Miguel et al., 2004; Unajak et al., 2011). The Extensive development of nucleic acid-based technologies over the past decades reflects their importance in food analysis. Various polymerase chain reactions (PCR) based approaches were attempted for meat authentication. In recent years, PCR coupled with molecular techniques, such as hybridization, nucleotide-sequencing, singlestrand conformation polymorphism (SSCP) or forensically informative nucleotide sequencing (FINS), were used for differentiation of buffalo meat from cattle meat (Murugaiah et al., 2009). The advantage of DNA-based analysis includes the ubiquity, abundance and stability of DNA in all cell types (Jain et al., 2007). PCR analysis of speciesspecific mitochondrial DNA (mtDNA) is the most common method currently used for meat species identification. The method is more sensitive in the identification of closely-related species as compared to nuclear DNA because each cell has only one set of genomic DNA in the nucleus, but bearing 104 copies of mtDNA (Parodi et al., 2002; Rastogi et al., 2007) with high mutation rate due to the poor corrective replication of polymerase and lack of proof-reading system in mitochondria. Following this approach, species-specific DNA in picograms (pg) can be detected in both processed and unprocessed meat samples. Genes to be targeted for amplification can be $12 \mathrm{~S}, 16 \mathrm{~S}$ and $18 \mathrm{~S}$ rRNA, actin, cytochrome b, cytochrome oxidaseII, NADH dehydrogenase 5/6 and mtD-loop (Girish and Nagappa, 2009; Kesmen et al., 2009). By using conventional multiplex PCR; many targets can simultaneously be amplified, which helps in detection of many species in a short period of time (Bai et al., 2009; Ghovvati et al., 2009; Girish and Nagappa, 2009). Heat-stable proteins have been 
reported to be useful targets for species identification of foods. However, methods based on DNA amplification are still preferred, as they are less affected by industrial processing (Edris et al., 2012; Pascoal et al., 2005). Generally, mitochondrial DNA (mtDNA) based PCR method was proved to be good option for the analysis of samples submitted to heat treatment in which DNA has been partly degraded (Rodriguez et al., 2004). With the emergence of real-time PCR technology, PCR methods for mitochondrial encoded targets (Lahiff et al., 2002) have been reported for the detection of bovine material in feeding stuff (Fajardo et al., 2008; Mafra et al., 2008).

The present work was planned to focus on the use of multiplex Polymerase Chain Reaction (mPCR) and the reliability of cytochrome $\mathrm{b}(c y t b)$ gene variability of mitochondrial DNA (mtDNA) in rapid detection and identification of four meat species as well as the prevalence of illegal adulteration by intermixing between meat types specially in case of processed meat products.

\section{MATERIAL AND METHODS}

\subsection{Primer sequences of species specific genes used for PCR identification system:}

Application of PCR for identification of $c y t b$ genes for differentiation of meat of different animal species was performed essentially by using primers (Pharmacia Biotech) as shown in the following table:

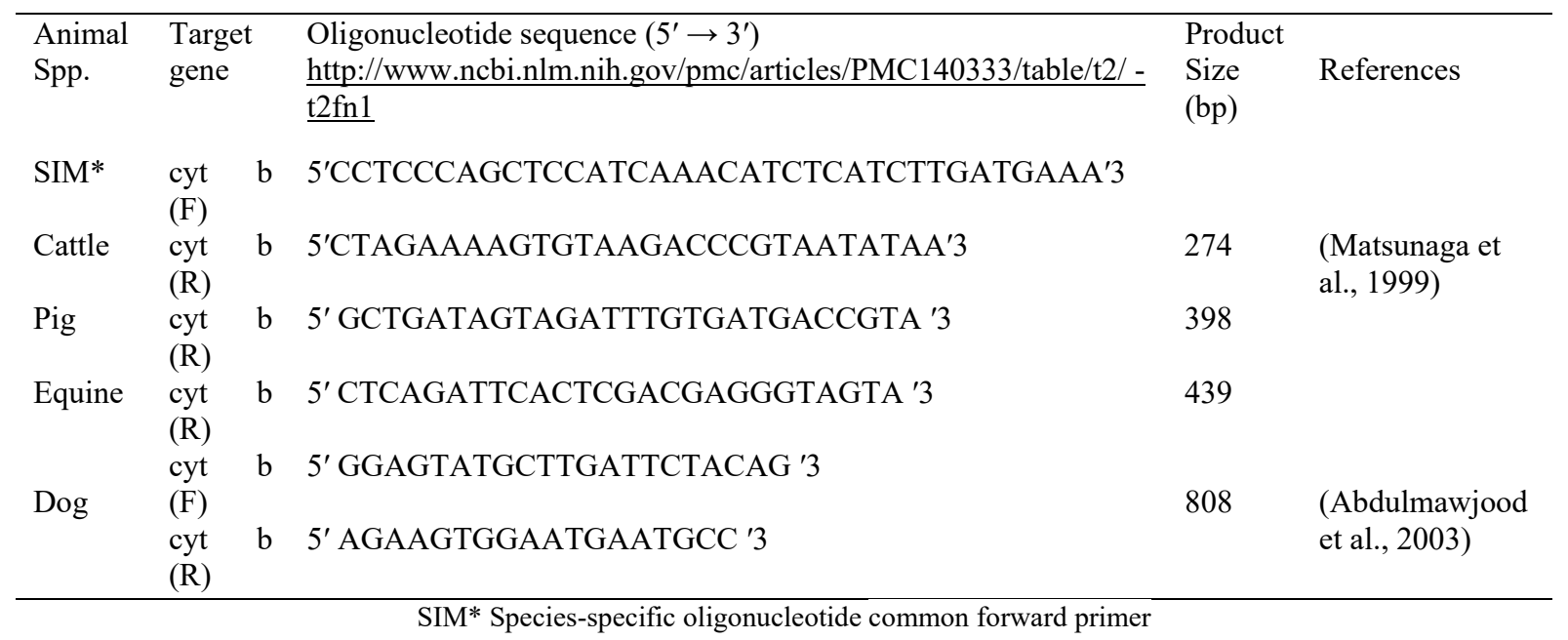

\subsection{DNA Extraction from the examined meat (Obrovska et al., 2002):}

Mitochondrial DNA (mtDNA) was extracted from muscle samples. Accurately, $500 \mathrm{mg}$ of muscle tissue was pulverized in liquid N2 and ground to powder, and mixed with $1 \mathrm{ml}$ Lysis buffer-ST $50 \mathrm{mM}$ Tris-HCI (pH-8.0), $10 \mathrm{mM}$ EDTA (pH-8.0), $100 \mathrm{mM} \mathrm{NaCl}, 150 \mu \mathrm{g} / \mathrm{ml}$ proteinase-K and SDS to make final concentration to $2 \%$. The samples were then incubated overnight at $55^{\circ} \mathrm{C}$ ensuring homogeneity. Incubated lysate was transferred to a clean tube; equal volume of tris-saturated phenol was added and mixed gently for $10 \mathrm{~min}$, followed by centrifugation for $10 \mathrm{~min}$ at $10000 \mathrm{rpm}$ at $15^{\circ} \mathrm{C}$. The aqueous phase was then re-extracted once with half the volume of tris-saturated phenol and twice with chloroform: isoamyl alcohol in the ratio of 24:1. The aqueous phase from the final chloroform/isoamyl alcohol extraction was transferred to a new tube and then precipitated by adding $1 / 20^{\text {th }}$ volume of $3 \mathrm{M}$ sodium acetate
(pH-5.5) and equal volume of isopropyl alcohol. The precipitated mitochondrial DNA was washed with $70 \%$ ethanol, dried and dissolved in $500 \mu \mathrm{l}$ of TE (10 M Tris-HCI, 1 mM EDTA, pH 8.0). The quality and purity of DNA were checked on agarose gel electrophoresis and quantitation done by UV-spectrophotometry.

\subsection{DNA amplification:}

2.3.1. Amplification reaction of cyt $b$ genes for cattle, pig and equine by multiplex PCR (Jain et al., 2007):

The amplification was performed on a Thermal Cycler (Master cycler, Eppendorf, Hamburg, Germany). PCR amplification was performed in a $25 \mu \mathrm{l}$ reaction volume containing $50 \mathrm{mM} \mathrm{KCI}$, $1.5 \mathrm{mM} \mathrm{MgCl} 2,200 \mu \mathrm{M}$ dNTP mix, primer mix (4-60 pmol each), 1.25 unit Taq DNA polymerase and $2 \mu \mathrm{l}$ (90 ng template DNA). Species-specific oligonucleotide primers consisting of common forward primer SIM for cattle, equine and pig meat were adopted. These primers were mixed in the 
ratio of 1: 0.6: 0.6: 2 for SIM: cattle: pork: equine and used together for the multiplex PCR. Amplification conditions consisted of an initial denaturation at $94^{\circ} \mathrm{C}$ followed by 31 cycles at $94^{\circ} \mathrm{C}$ for $30 \mathrm{sec}$, annealing at $60^{\circ} \mathrm{C}$ for $30 \mathrm{sec}$, extension at $72^{\circ} \mathrm{C}$ for $30 \mathrm{sec}$ and final extension at $72^{\circ} \mathrm{C}$ for 10 min using a thermal cycler. Molecular size markers were indicated on each gel. The products of PCR amplification were analyzed by agarose gel electrophoresis. Amplified DNA fragments were analyzed by $4 \%$ of agarose gel electrophoresis (Applichem, Germany, $\mathrm{GmbH}$ ) in $5 \mu \mathrm{l} / 100 \mathrm{ml}$ TBE buffer stained with ethidium bromide and captured as well as visualized on UV transilluminator. Electrophoretic separation of DNA fragments was done at $100 \mathrm{~V}$ for $60 \mathrm{~min}$. A 100 bp plus DNA Ladder (Qiagen, Germany, $\mathrm{GmbH}$ ) was used to determine the fragment sizes.

\subsubsection{Amplification reaction of cyt $b$ gene for detection of dog's meat (Edris et al., 2012):}

Actually, the reaction volumes of $50 \mu$ were performed using $1 \mathrm{ng}$ of genomic DNA of suspected meat, 25 pmoles of the primer, $1 \mathrm{x}$ Taq DNA polymerase buffer, $2 \mathrm{mM} \mathrm{MgCl} 2,0.2 \mathrm{mM}$ dNTPs and 0.2 Taq DNA polymerase PCR. The amplification consisted of initial denaturation at $94^{\circ} \mathrm{C}$ for $4 \mathrm{~min}$, followed by 35 cycles each at $94^{\circ} \mathrm{C}$ for 60 secs, annealing temperature at $48{ }^{\circ} \mathrm{C}$ to $58^{\circ} \mathrm{C}$ for $60 \mathrm{sec}$. The polymerization temperature at $72^{\circ} \mathrm{C}$ for $60 \mathrm{~s}$ and final extension at $72^{\circ} \mathrm{C}$ for $10 \mathrm{~min}$, then, the samples were held at $4^{\circ} \mathrm{C}$. The amplified mtDNA fragments were separated on $2 \%$ agarose gel, stained with ethidium bromide, visualized on a UV transilluminator and photographed.

\section{RESULTS}

PCR was planned to amplify partial length $c y t b$ gene differing in amplicon sizes for the identification of different meat species. The obtained results indicated successful amplification of the target cyt b gene sequences with the expected amplicon sizes $(274,398,439$ and $808 \mathrm{bp})$ for cattle, pig, equine and dog's meat, respectively. The results recorded in the present study revealed that multiplex PCR could detect one sample (10\%) out of 10 examined cattle minced meat samples was intermixed with equine meat. As shown in Photograph (1) and Fig. (1). Moreover, Photograph (2) and Fig. (1) Showed that two samples (20\%) out of 10 examined sausages were found to be adulterated with equine meat. While, examined luncheon samples were free from intermixing with both equine or pig meat as shown in Photograph (3) and Fig. (1).

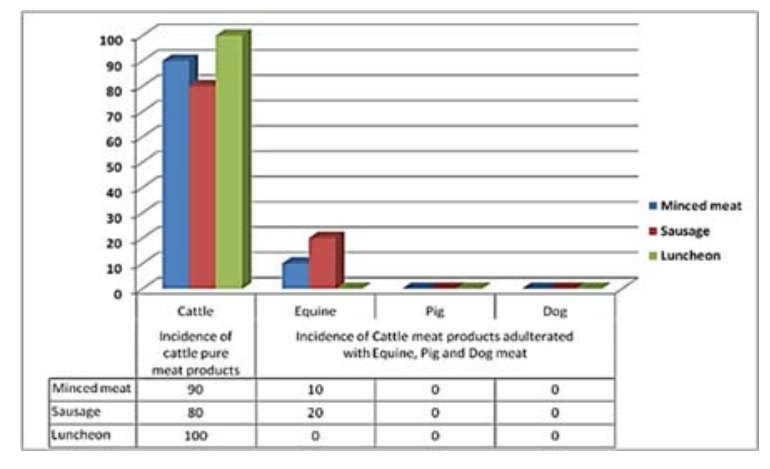

Fig. (1) No. of intermixed beef samples with either equine, pork, or dog meat

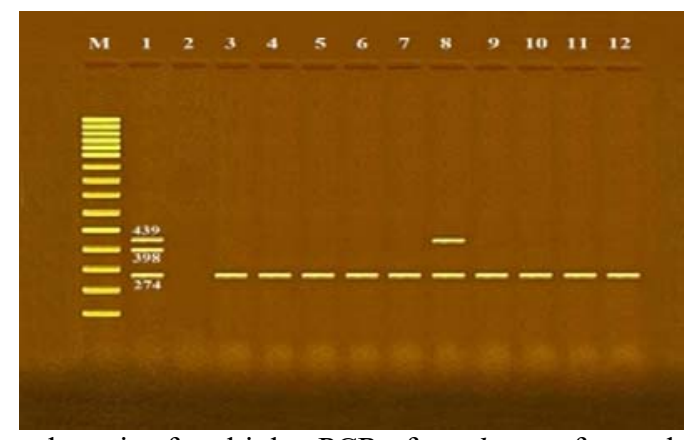

Photograph (1): Agarose gel electrophoresis of multiplex PCR of cyt b gene for cattle (274 bp), pig (398 bp) and equine (439 bp) meat for demonstration of minced meat adulteration. Lane M: 100 bp ladder as molecular size DNA marker. Lane 1: Control positive for cyt b gene of cattle, pig and equine meat. Lane 2: Control negative. Lanes 3, 4, 5, 6, 7, 9, 10, 11 \& 12: Pure cattle meat. Lane 8: cattle minced meat sample (No. 8) was intermixed with equine one. 


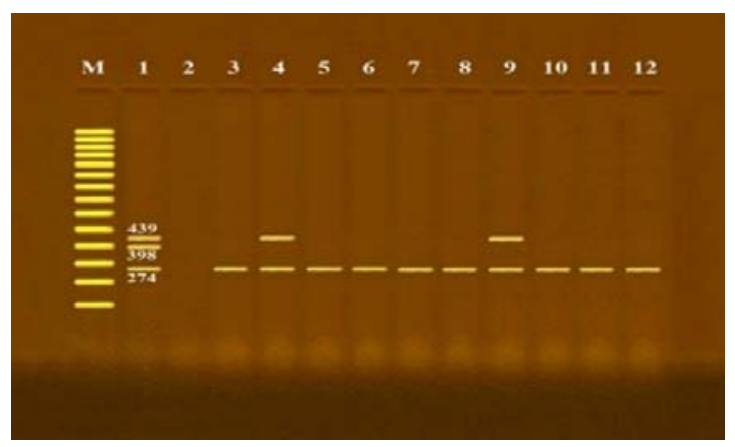

Photograph (2): Agarose gel electrophoresis of multiplex PCR of cyt $b$ gene for cattle (274 bp), pig (398 bp) and equine (439 bp) for demonstration of sausage adulteration. Lane M: $100 \mathrm{bp}$ ladder as molecular size DNA marker. Lane 1: Control positive for cyt $b$ gene of cattle, pig and equine meats. Lane 2: Control negative. Lanes 3, 5, 6, 7, 8, 10, $11 \&$ 12: Pure cattle meat. Lanes $4 \&$ 9: Cattle meat samples No. $4 \& 9$ were intermixed with equine meat.

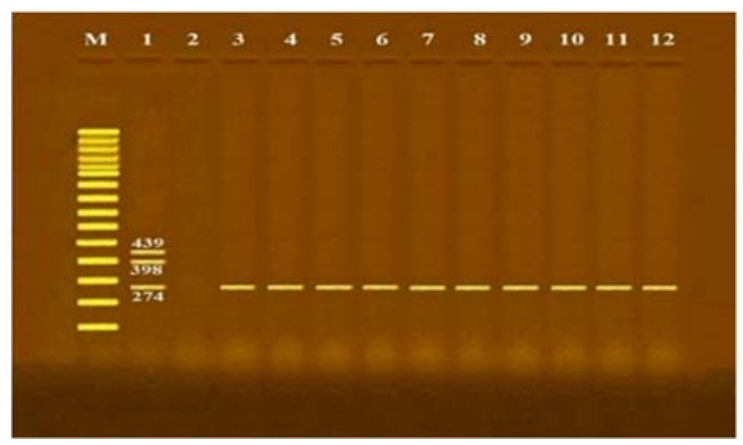

Photograph (3): Agarose gel electrophoresis of multiplex PCR of cyt b gene for cattle (274 bp), pig (398 bp) and equine (439 bp) for demonstration of luncheon adulteration. Lane M: $100 \mathrm{bp}$ ladder as molecular size DNA marker. Lane 1: Control positive for cyt $b$ gene of cattle, pig and equine meats. Lane 2: Control negative. Lanes from 3 to 12: Pure cattle meat.

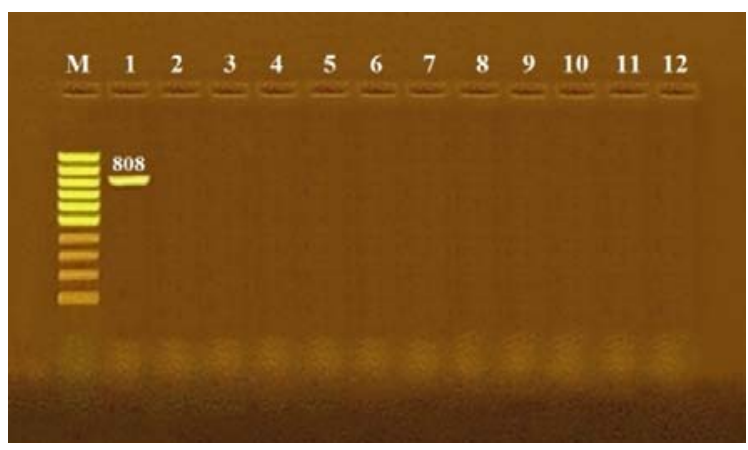

Photograph (4): Agarose gel electrophoresis of uniplex PCR of cyt b gene. Specific for dog meat (808 bp) for demonstration of adulteration of meat products (minced meat, sausage and luncheon meat). Lane M: $100 \mathrm{bp}$ ladder as molecular size DNA marker. Lane 1: Control positive for cyt $b$ gene dog meat. Lane 2: Control negative. Lanes from 3 to 12: Pure cattle meat free from dog meat.

On the other hand, all examined meat product samples were found to be free from adulteration with addition of dog meat (Photograph 4) using uniplex PCR.

\section{DISCUSSION}

The obtained results in the present study agreed with that reported by Ghovvati et al. (2009) who recorded that none of the examined meat product samples were contaminated with porcine residuals. Moreover, Yosef et al. (2014) found that eight luncheon meat $(72.7 \%)$ and $6(54.5 \%)$ of sausage samples were adulterated with addition of other 
meat types, the author added that only one sample each of luncheon and sausage was adulterated with addition of pig meat. These incidences were higher than that recorded in the present study. The authors added that no meat of equine species was detected in any of the examined samples. A multiplicity of meat adulteration particularly in processed meat products were recorded in past studies from different countries such as Australia, Canada, Egypt, Saudi Arabia, Turkey, United Kingdom and USA (Abd El-Naseer et al., 2010; Ayaz et al., 2006; D'Amato et al., 2013; El-Sangary and Gabrail, 2006; Ibrahim, 2008). Moreover, Frank and Hahn (2003) stated that fraud of meat products inconsistent with federal or state standards. Adulteration usually refers to noncompliance with health or safety standards as determined in the United States by (Food and Drug Administration "FDA", 2000).

Margawat et al. (2011) found that five minced beef samples were contaminated with pork meat. They concluded that, the common differences in PCR results might be due to differences in setting up the time and temperature of each PCR step among researchers and might be differences in each concentration of reaction compounds. Moreover, Sakalar and Abasiyanik (2011) declared that $40 \%$ of the commercially labeled meat products were adulterated with different meat species which were not referred in their labels.

In this respect, Abbas et al. ( 2014) stated that 6 $(8.82 \%)$ out of 68 fermented sausages were found to contain Haram (unlawful or prohibited) meat. They added that molecular methods as PCR are potentially reliable techniques mitochondrial DNA segment (cytochrome-b gene) for detection of meat type in meat products for Halal authentication. In this regards, Abd El-Naseer et al. (2010) found that $57 \%$ and $66.7 \%$ of examined minced meat and sausage samples were adulterated with addition of other meat, out of which $35.7 \%$ and $41.7 \%$ were adulterated with pork meat, while $7 \%$ and $8 \%$ were adulterated with donkey meat, respectively. This substantiates the findings in the present investigation regarding adulteration of $10 \%$ of examined cattle minced meat samples with equine meat

The target genes and DNA fragments used as markers for identifying meat species mainly comes from the mitochondrial genome, (mtDNA) including 12S rRNA gene (Wang et al., 2010), $16 \mathrm{~S}$ RNA gene (Mitani et al., 2009) and cyt b gene (Ahmed and Abdel-Rahman, 2007; Murugaiah et al., 2009).
Food composition and authenticity is becoming a very important issue by avoiding unfair competition among producers, allowing consumers to have accurate information about the acquired products. According to the European Union labeling regulations, meat products should be accurately labeled regarding their species content (European Commission, 2001). Quality evaluation of these products encompasses many issues, such as the fraudulent substitution of higher commercial value meat by lower value meat (Fajardo et al., 2008). Moreover, the presence of undeclared ingredients may be troublesome for health reasons, such as in the case of bovine spongiform encephalopathy due to the addition of infected neurological tissue and because of allergic reactions in sensitized individuals (Asensio et al., 2008b) or in case of addition of pork meat affected with Influenza virus.

The most important problem to be considered in meat species adulteration is related to religious practices as in some religions, such as Islam, pork meat consumption considered forbidden. Although, the species of origin in raw meat can be identified by using most of protein-based methods, some authors showed that they are significantly less sensitive in the evaluation of thermally processed foods because of epitopes alterations (Rodriguez et al., 2004).

Mitochondrial DNA (mtDNA) molecules coupled polymerase chain reaction represents a fast, sensitive and highly specific alternative to protein-based methods (Mafra et al., 2008). PCR has demonstrated to be a useful tool for the determination of minute amounts of different species, even in complex foodstuffs (Fajardo et al., 2008; Mafra et al., 2008). Real-time PCR is probably the most used quantitative mtDNA-based method; however, the high cost of the equipments and reagents is still a drawback for the application of this technique in most laboratories. Alternatively, other approaches based on multiplex PCR for quantitative analysis have been tested and recommended (Mafra et al., 2007), the author claimed that multiplex PCR was efficient enough to detect as little as $5 \%$ (5 pg DNA contaminants) of others animal species.

\section{CONCLUSION AND RECOMMENDATIONS}

This study suggests an analytical technique for detecting meat adulteration by conventional multiplex PCR analysis of the cyt $b$ gene of animal mtDNA. This technique was used to detect and trace meat adulteration and to differentiate species present in meat mixture. Adulteration is a serious 
food safety and quality issue with an increasing prevalence in meat and meat products all over the world. Regular controls for adulteration in meat and meat products should be frequently and intensively done due to the significant increasing demand for the meat. It was found that conventional multiplex PCR of greater potency and should extensively be promoted for differentiation of animal species and detection of the fraud existed in meat and meat products. A well recognized drawback for PCR methods is that they are susceptible to contamination and thus delicate facilities and extreme caution is needed. The Governments should apply more restricted laws through various religious, political, educational and scientific bodies to create an awareness program for its citizens with regard to the religious and aspects of the food being consumed. It is necessary to apply this technique by quality control laboratories for routine assessment of meat fraud in a rapid and reliable way.

\section{REFERENCES}

Abbas, D., Payam, G., Dehkordi, E., 2014. Molecular assay to fraud identification of meat products J Food Sci. Technol. 51, 148152.

Abd El-Naseer, M., Labieb, H.Y., Doaa, M.A.E.A., 2010. Identification of meat species in some meat products in Assiut city Ass. Univ. Bull. Environ. Res. 13, 1-13.

Abdulmawjood, A., Schonenbrucher, H., Bulte, M., 2003. Development of a polymerase chain reaction system for the detection of dog and cat meat in meat mixtures and animal feed. J Food Sci. Technol. 68: , 17571761.

Ahmed, M.M., Abdel-Rahman, S.M., 2007. Application of species-specific polymerase chain reaction and cytocrome $b$ gene for different meat species authentication. . Biotechnology 6, 426-430.

Asensio, L., Gonzalez, I., Gracía, T., Martín, R., 2008a. Determination of food authenticity by enzyme-linked immunosorbent assays (ELISA) Food Control 19, 1-8.

Asensio, L., Gonzalez, I., Pavon, M.A., Gracía, T., Martin, R., 2008b. An indirect ELISA and a PCR technique for the detection of grouper (Epinephelus marginatus) mislabeling. Food Additives and Contaminants Part A Chemistry, Analysis, Control, Exposure and Risk Assessment 25, 677- 683.

Ayaz, Y., Ayaz, N., Erol, I., 2006. Detection of species in meat and meat products using enzyme-linked immunosorbent assay J. Muscle Foods 17, 214-220.

Bai, W., Xu, W., Huang, K., Yuan, Y., Cao, S., Luo, Y., 2009. A novel common primer multiplex PCR (CP-M-PCR) method for the simultaneous detection of meat species Food Control 20, 366-370.

D'Amato, M., Alechine, E., Cloete1, K., Davison, S., Corach, D., 2013. Where is the game? Wild meat products authentication in South Afra a case study Investigative Genetics 4.

Edris, S., Mutwakil, M.H.Z., Abuzinadah, O.A., Mohammed, H.E., Ramadan, A., Gadalla, N.O., Shokry, A.M., Hassan, S.M., Shoaib, R.M., El-Domyati, F.M., Bahieldin, A., 2012. Conventional multiplex polymerase chain reaction (PCR) versus real-time PCR for species-specific meat authentication. Life Sci J 9, 5831-5837.

El-Sangary, R., Gabrail, G., 2006. Differentiation between different animal meats using species specific Polymerase Chain Reaction technique, Fac. Vet. Med., Assiut Univ. Egypt.

European Commission, 2001. Directive 2001/101/EC of 26 November 2001 amending Directive 2000/13/EC of the European Parliament and of the Council on the approximation of 20 March 2000 on the approximation of the laws of the Member States relating to the labeling, presentation and advertising of foodstuffs. Official Journal of the European Communities L. $310,19-21$.

Fajardo, V., González, I., Martín, I., Rojas, M., Hernández, P.E., García, T., 2008. Real-time PCR for detection and quantification of red deer (Cervus elaphus), fallow deer (Dama dama), and roe deer (Capreolus capreolus) in meat mixtures Meat Sci 79 289-298.

Food and Drug Administration "FDA", 2000. Office of Regulatory Affairs. Compliance Policy Guides Manual. Washington, D.C.: Government Printing Office, 2000; updated 2001 Available at http://www.fda.gov/ora/compliance ref/cpg default.htm.

Frank, R.L., Hahn, R.A., 2003. "Adulteration of Food." Encyclopedia of Food and Culture. Encyclopedia.com. 29 Jun. 2016, http://www.encyclopedia.com.

Ghovvati, S., Nassiri, M.R., Mirhoseini, S.Z., Heravi, M.A., Javadmanesh, A., 2009. Fraud identification in industrial meat products by multiplex PCR assay Food Control 20, 696699. 
Girish, P.S., Nagappa, K., 2009. Molecular techniques for meat species identification. In: Proceedings of the Recent Developments in Post-harvest Processing and Value Addition in Livestock product. . Ciphet, Ludhiana.

Ibrahim, A., 2008. Improved DNA Extraction Method for Porcine Contaminants, Detection in Imported Meat to the Saudi Market Saudi J. Biological Sci. 15, 225-229.

Jain, S., Brahmbhatt, M.N., Rank, D.N., Joshi, C.G., Solanki, J.V., 2007. Use of cytochrome $b$ gene variability in detecting meat species by multiplex PCR assay. Indian J Anim Sci 77, 880-881.

Kesmen, Z., Gulluce, A., Sahin, F., Yetim, H., 2009. Identification of meat species by TaqMan-based real-time PCR assay Meat Sci 82, 444-449.

Lahiff, S., Glennon, M., Lyng, J., Smith, T., Shilton, N., Maher, M., 2002. Real-time polymerase chain reaction detection of bovine DNA in meat and bone meal samples. J. Food Prot 65, 1158-1165.

Mafra, I., Ferreira, I., Oliveira, M., 2008. Food authentication by PCR-based methods Eur. Food Res Tech 227 649-665.

Mafra, I., Roxo, A., Ferreira, I., Oliveira, M., 2007. A duplex polymerase chain reaction for the quantitative detection of cow's milk in goats' milk cheese Intl Dairy J. 17 1132-1138.

Margawat, E.T., Ridwan, M., Indriawati, 2011. A Sensitive Method for Identification of porcine contaminant in unprocessed food by PCR Amplification Technique Biota 16, 342-347.

Matsunaga, T., Chikuni, K., Tanabe, R., Muroya, S., Shibata, K., Yamada, J., Shinmura, Y., 1999. A quick and simple method for the identification of meat species and meat products by PCR assay Meat Sci 51 143148.

Miguel, A.R., Teresa, G., Isabel, G., Luis, A., Pablo, E.H., Rosario, M., 2004. PCR identification of beef, sheep, goat and pork in raw and heat treated meat mixtures Journal of Food Protection 67, 172-177.

Mitani, T., Akane, A., Tokiyasu, T., Yoshimura, S., Oki, Y., Yoshida, M., 2009. Identification of animal species using the partial sequences in the mitochondria 16S rRNA gene Leg. Med. 11 S449-S450.
Murugaiah, C., Mohd, N., Mastakim, M., Maurice, B., Selamat, J., Son, R., 2009. Meat species identification and Halal authentication analysis using mitochondrial DNA Meat Sci 83, 57-61.

Obrovska, I., Steinhauserova, I., Nebola, M., 2002. The application of the PCR method to the identification of meat species Folia Veterinaria 46 113-118.

Parodi, B., Aresu, O., Bini. D., Lorenzini, R., Schena, F., Visconti, P., 2002. Species identification and confirmation of human and animal cell lines: a PCR based approach Biotechnology 32, 433-440.

Pascoal, A., Prado, M., Calo, P., Cepeda, A., Velásquez, J.B., 2005. Detection of bovine DNA in raw and heat-processed foodstuffs, commercial foods and specific risk materials by a novel specific polymerase chain reaction method Eur. Food Res Technol 20, 444-450.

Rastogi, G., Dharne, M.S., Walujkar, S., Kumar, A., Patole, M.S., Shouche, Y.S., 2007. Species identification and authentication of tissues of animal origin using mitochondrial and molecular markers Meat Sci 76, 666674.

Rodriguez, M.A., García, T., González, I., Asensio, L., Hernández, P.E., Martín, R., 2004. PCR identification of beef, sheep, goat, and pork in raw and heat treated meat mixtures $\mathrm{J}$. Food Prot. 67, 172-177.

Sakalar, E., Abasiyanik, M.F., 2011. Qualitative analysis of meat and meat products by multiplex polymerase chain reaction (PCR) technique African J. of Biotech. 10, 93799386.

Unajak, S., Meesawat, P., Anyamaneeratch, K., Anuwareepong, D., Srikulnath, K., Choowongkomon, K., 2011. Identification of species (meat and blood samples) using nested-PCR analysis of mitochondrial DNA African J. Biotech. 10, 5670-5676.

Wang, Q., Zhang, X., Chen, G., Zhao, D., Ma, H., Liao, W., 2010. Identification of 12 animal species meat by T-RFLP on the gene Meat Sci. 85 265-269.

Yosef, T.A., Al-Julaifi, M.Z., Al-Rizqi, A.M., 2014. Food Forensics: Using DNA-Based Technology for the Detection of Animal Species in Meat Products Nature and Sci. 12, 82-90. 